\title{
Pengaruh Kompensasi Terhadap Kinerja Karyawan Pada PT. JAEIL INDONESIA
}

\author{
Agung Surya Dwianto \\ Universitas Negeri Jakarta (UNJ) \\ Lecturer at STIE Pertiwi \\ adwianto11@gmail.com \\ Pupung Purnamasari \\ Universitas Pendidikan Indonesia (UPI) \\ Lecturer at STIE Pertiwi \\ pupungpurnamasarisuryadinata@gmail.com
}

\section{Tukini}

STIE Pertiwi

\begin{abstract}
Compensation is a complicated and classic problem that has plagued the industrial world. As is known that the provision of appropriate compensation which given by the company, is one of the main factors that influence the improvement of employee performance. In Indonesia, the issue of providing compensation has been regulated in the labor law. The government in this case the Ministry of Manpower always emphasizes to all companies operating in Indonesia, in order to obey and implement all provisions regulated by law. This research was conducted at a company located in Bekasi, precisely in Jababeka - Cikarang, which is at PT. Jaeil Indonesia. The purpose of this study is to determine the extent to which compensation can increase employee performance, especially in the Production Department of PT. Jaeil Indonesia. This type of research is quantitative research, in which the objects in this study amounted to 40 employees of the Production Department of PT. Jaeil Indonesia. The analytical method used is a simple linear regression method. Meanwhile, data was collected through questionnaires and analyzed using SPSS version 24. The results of this study indicate that the value of $R^{2}$ is 0.486 , meaning the percentage of the effect of compensation for employee performance is $48.6 \%$ while the rest is influenced by other variables not examined in this study. The results of the $t$ test show that the value of t count is greater than the value of t table (5.146> 2.048). This shows that the hypothesis used in this study is accepted, that is there is an effect of giving compensation to the performance of employees in the Production Department of PT. Jaeil Indonesia, so companies need to pay attention to employees by adjusting the compensation with the workload they bear according to the prevailing laws and regulations.
\end{abstract}


Keywords Compensation and employee performance

\section{PENDAHULUAN}

Perusahaan adalah suatu lembaga yang diorganisir dan dijalankan untuk menyediakan barang dan jasa agar dapat melayani permintaan konsumen akan kebutuhan mereka. Dalam melaksanakan proses produksinya, suatu perusahaan membutuhkan faktor-faktor produksi yang dapat menunjang tercapainya tujuan perusahaan, faktor-faktor tersebut adalah bahan baku, modal dan manusia.

Khususnya pada faktor manusia, faktor ini memegang peranan yang sangat penting dalam melaksanakan proses produksi. Oleh karena itu pihak perusahaan harus selalu memperhatikan faktor manusia atau tenaga kerja yang dapat menentukan keberhasilan perusahaan dalam mencapai tujuannya. Secanggih apapaun peralatan yang dimiliki perusahaan tidak akan bisa mencapai tingkat kinerja yang diharapkan jika peralatan tersebut tidak dioperasikan secara efektif dan efisien oleh sumber daya manusia yang dimiliki perusahaan tersebut.

Yani dalam Mulyadi (2015:2) menyatakan bahwa Manajemen Sumber Daya Manusia (MSDM) dapat diartikan sebagai ilmu dan seni yang mengatur hubungan dan peranan tenaga kerja secara efektif dan efisien sehingga tercapai tujuan organisasi atau perusahaan.

Dari pendapat diatas terlihat bahwa sumber daya manusia merupakan faktor penentu dalam memenangkan persaingan bisnis dan tercapainya tujuan organisasi. Manajer yang berhasil adalah mereka yang mampu melihat sumber daya manusia sebagai aset yang harus dikelola sesuai dengan kebutuhan bisnis.

Perubahan lingkungan bisnis sangat cepat. hal ini menuntut perusahaan dapat menciptakan kinerja karyawan yang tinggi untuk mengembangkan perusahaan. Tentunya hal tersebut menuntut peran Sumber Daya Manusia dalam keunggulan bersaing. Ini berarti bahwa organisasi harus dapat meningkatan hasil kerja yang lebih baik di masa depan. Peningkatan kinerja karyawan dapat terwujud dengan pemberian kompensasi dan sikap kerja yang maksimal, serta aspek lain yang dapat mempengaruhi kinerja.

Sastrohadiwiryo dalam Sinambela (2018:218) menyatakan bahwa:

"Kompensasi adalah Imbalan jasa atau balas jasa yang diberikan oleh organisasi kepada para tenaga kerja karena tenaga kerja tersebut telah memberikan sumbangan tenaga dan pikiran demi kemajuan organisasi guna mencapai tujuan yang telah di tetapkan”.

Keberhasilan dalam menentukan kompensasi yang layak akan menentukan bagaimana kualitas SDM dalam bekerja, yang secara langsung akan berkaitan dengan efektivitas tujuan pegawai dan efisiensi anggaran organisasi, serta akan menentukan bagaimana keberlangsungan hidup organisasi dalam lingkungan persaingan bisnis yang semakin kompetitif. Kompensasi yang memadai akan mempengaruhi kinerja yang ditampilkan oleh pegawai. Ketika kompensasi tidak sesuai dengan harapan para pegawai maka yang terjadi adalah penolakan secara halus sampai dengan penolakan secara keras melalui demonstrasi.

PT. JAEIL INDONESIA merupakan perusahaan yang bergerak di bidang manufaktur Mold Injection, Dengan 115 karyawan terdiri dari 3 satpam, 20 Staff sisanya 92 karyawan bagian warehouse dan produksi. Berdasarkan hasil pengamatan sementara ini PT. JAEIL INDONESIA dalam memberikan kompensasi terhadap karyawan bagian produksi belum 
memadai seperti yang sudah ditetapkan pada batas upah minimum regional untuk wilayah Cikarang.

Tabel

Data UMK Kota Cikarang

\begin{tabular}{|l|l|}
\hline Tahun & UMK \\
\hline 2016 & Rp. 3.456.000 \\
\hline 2017 & Rp 3.725.000 \\
\hline 2018 & Rp 3.890.000 \\
\hline
\end{tabular}

Sumber: bekasi.go.id

Sedangkan PT. JAEIL INDONESIA memberikan kompensasinya per bulan di angka 3.250.000, bahkan kurang dari 3.250.000 bagi karyawan yang absensinya tidak full 1 (satu) bulan kerja karena jika karyawan tidak hadir maka upah pun akan dipotong. Dari hal tersebut menyebabkan tingginya turn-over pada karyawan baru di bagian produksi, rata-rata karyawan baru hanya bertahan 1 sampai 2 bulan yang mana pada waktu singkat tersebut karyawan baru belum menguasai tugas tugasnya namun sudah mengundurkan diri, Absensi kehadiran karyawan yang tidak bagus yaitu sering adanya mangkir atau ijin sakit yang terlalu lama sehingga pekerjaan pun dibebankan kepada karyawan lain sebagai bentuk over time dengan imbalan 15.000 per jam, Akibat dari tidak standarnya gaji yang diterima oleh karyawan PT. Jaeil Indonesia menyebabkan kinerja tidak stabil bahkan mengalami penurunan kualitas produk.

Adapun data pemberian kompensasi PT. JAEIL INDONESIA adalah sebagai berikut:

Tabel

Data Gaji Karyawan Bagian Produksi PT. Jaeil Indonesia Periode 2016-2018

\begin{tabular}{|c|c|c|c|}
\hline No & Tahun & Bagian & Penghasilan \\
\hline 1 & 2016 & Poduksi & Rp 3.250.000/bln \\
\hline 2 & 2017 & Produksi & Rp 3.250.000/bln \\
\hline 3 & 2018 & Produksi & $\operatorname{Rp} 3.250 .000 / b \ln$ \\
\hline
\end{tabular}

Sumber: HRD PT. Jaeil Indonesia

Tabel diatas adalah contoh gaji yang diterima oleh karyawan produksi setiap bulan berdasarkan jumlah hari kerja, karyawan produksi memiliki hitungan hari kerja rata-rata 30 HK/ Rp 3.250.000. Maka jika karyawan tersebut libur di hari sabtu atau minggu bahkan tanggal merah sekalipun secara otomatis hari kerja akan berkurang dan hasilnya tidak akan pernah sampai di $30 \mathrm{HK}$ begitu juga dengan gaji yang mereka terima. Adapun hitungan $26 \mathrm{HK} / \mathrm{Rp}$ 3.288.909 itu berlaku untuk kepala di bagian produksi yang meliputi kepala QC, kepala WH dan kepala produksi. Berdasarkan contoh tabel gaji yang diterima oleh karyawan produksi, menyebabkan seringnya karyawan mangkir yang kemudian berakhir pada resign. 
Anwar Prabu Mangkunegara (2015:67) menyatakan bahwa:

"Kinerja adalah hasil kerja secara kualitas dan kuantitas yang dicapai oleh seorang pegawai dalam melaksanakan tugasnya sesuai dengan tanggung jawab yang diberikan kepadanya".

Suatu organisasi atau perusahaan dapat dikatakan bagus jika hasil kerja yang di dapatkan oleh pegawainya sesuai dengan standar kuantitas dan kualitas perusahaan, Dan sebaliknya jika pegawai menghasilkan kinerja yang tidak sesuai standar perusahaan baik secara kualitas dan kuantitas maka tidak menutup kemungkinan perusahaan tersebut akan mengalami kerugian, baik kerugian biaya maupun waktu. Seperti yang ada pada PT. JAEIL INDONESIA dalam beberapa semester ini hasil produksi secara kualitas menurun, pernyataan tersebut di dapat dari banyaknya jumlah hasil produksi yang NOT GOOD (NG) sehingga barang tidak dapat di kirimkan ke customer sesuai dengan quantity permintaan.

Adapun grafik yang menunjukan prosentase NG adalah sebagai berikut:

\section{Grafik Data "Not Good” Bagian Produksi}

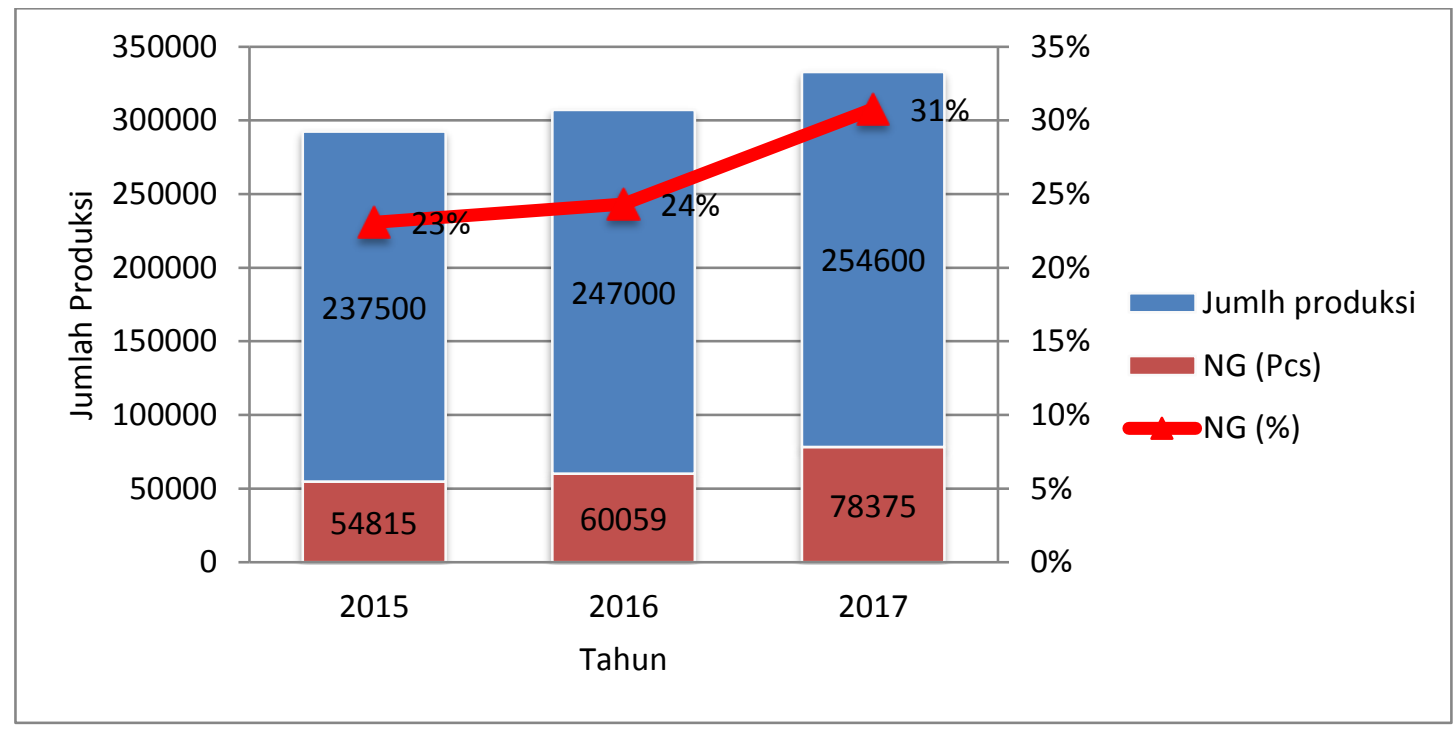

Dari data di atas, terlihat bahwa Produk NG atau hasil produksi yang tidak standar di PT. JAEL INDONESIA cukup tinggi, hal tersebut dapat mempengaruhi tercapainya tujuan organisasi.

Keterkaitan antara pemberian kompensasi terhadap kinerja dikemukakan oleh Sondang P. Siagian (2015) Menyatakan sistem kompensasi yang baik adalah sistem yang mampu menjamin kepuasan para anggota organisasi yang pada gilirannya memungkinkan organisasi memperoleh dan mempekerjakan orang yang memilki sikap dan perilaku positif dan bekerja dengan produktif bagi kepentingan organisasi guna mencapai tujuannya.

\section{Telaah Pustaka}

Untuk meningkatakan produktivitas dan memotivasi karyawan, maka perusahaan perlu memberikan kompensasi kepada karyawan. Agar karyawan yang cakap masuk ke dalam 
organisasi, untuk mendorong karyawan berprestasi tiggi, untuk mempertahankan karyawan produktif dan berkualitas agar tetap setia kepada organisasi/perusahaan.

Sastrohardiwiryo dalam Sinambela (2018:218) menyatakan bahwa "Kompensasi adalah imbalan jasa atau balas jasa yang diberikan oleh organisasi kepada para tenaga kerja karena tenaga kerja tersebut telah memberikan sumbangan tenaga dan pikiran demi kemajuan organisasi guna mencapai tujuan yang telah ditetapkan”.

Menurut Sutrisno (2009 : 89) menyatakan bahwa "Kompensasi merupakan salah satu fungsi yang penting dalam manajemen sumber daya manusia (MSDM). Karena kompensasi merupakan salah satu aspek yang paling sensitif didalam hubungan kerja".

J long dalam Sinambela (2018:219) menyatakan bahwa "Kompensasi adalah bagian dari system reward yang hanya berkaitan dengan bagian ekonomi, tetapi sejak adanya keyakinan bahwa perilaku individual dipengaruhi oleh system dalam spectrum yang lebih luas maka system kompensasi tidak dapat terpisah dari keseluruhan system reward yang disediakan oleh organisasi”.

Handoko dalam Edy Sutrisno (2009:183) menyatakan bahwa:

"Kompensasi adalah segala sesuatu yang diterima oleh karyawan sebagai balas jasa untuk kerja mereka".

Dari beberapa pendapat para ahli diatas, maka dapat disimpulkan bahwa kompensasi adalah hak karyawan setelah memberikan tenaga, pikiran serta waktu dan diberikan oleh perusahaan berdasarkan kebijakaan, yang dapat mempengaruhi kinerja selanjutnya.

Fungsi dan Tujuan Kompensasi

Menurut Notoadmojo dalam Edy Sutrisno (2009:188) ada beberapa tujuan dari kompensasi yang perlu diperhatikan, yaitu:

1. Menghargai prestasi kerja

2. Menjamin keadilan

3. Mempertahankan karyawan.

4. Memperoleh karyawan yang bermutu

5. Pengendalian biaya

6. Memenuhi peraturan-peraturan

\section{Sistem Kompensasi}

Sinambela (2018:228) menyatakan bahwa pengembangan sistem kompensasi organisasi perlu dilakukan dengan berbagai strategi yang saling mendukung. Strategi tersebut antara lain berkenaan dengan:

1. Analisis pekerjaan, perlu disusun deskripsi jabatan, uraian pekerjaan dan standar pekerjaan, yang terdapat dalam suatu organisasi.

2. Penilaian pekerjaan yang dikaitkan dengan keadilan internal. Dalam melakukan penilaian pekerjaan diuasahakan tersusunya urutan peringkat pekerjaan, penetuan "nilai" untuk 
setiap pekerjaan, susunan perbandingan dengan pekerjaan lain dengan organisasi dan pemberian poin untuk setiap pekerjaan.

3. Survei berbagai system kompensasi. Dengan melakukan survey berbagai sistem kompensasi yang berlaku guna memperoleh bahan yang berkaitan dengan keadilan eksternal. Organisasi yang di survey dapat brupa instansi pemerintah yang secara fungsioanl berwenang mengurus ketenagakerjaan, kamar dagang dan industry, organisasi profesi, serikat pekerja, organisasi pemakai pegawai lain dan organisasi konsultan, terutama yang mengkhususkan diri dalam manajemen.

Kinerja

Menurut Mangkunegara

, (2015:67) menyatakan bahwa "Definisi kinerja karyawan sebagai hasil kerja secra kuantitas dan kualitas yang dicapai oleh seseorang karyawan dalam melaksanakan tugasnya sesuai dengan tanggung jawab yang diberikan kepadanya".

Sedangkan faktor yang mempengaruhi kinerja adalah faktor kemampuan (Ability) dan faktor Motivasi (Motivation). Hal ini sesuai dengan pendapat Keith Davis dalam Mangkunegara (2015:67) yang merumuskan bahwa:

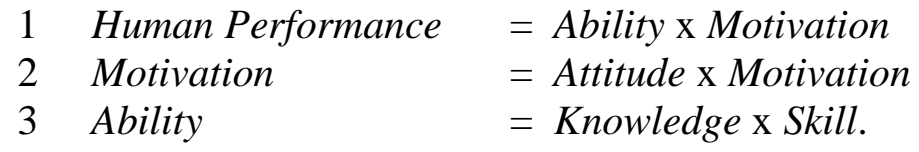

Penilaian Kinerja berikut:

Penilaian prestasi menurut Manggison dalam Mangkunegara (2014:10) adalah sebagai

"Penilaian prestasi kerja (Performance appraisal) adalah suatu proses yang digunakan pimpinan untuk menentukan apakah seorang karyawan melakukan pekerjaanya sesuai dengan tugas dan tanggung jawab".

Menurut Simanjuntak dalam Sinambela (2018:519) menyatakan bahwa:

"Evaluasi kinerja adalah suatu metode dan proses penilaian pelaksanaan tugas seseorang, sekelompok orang, unit-unit kerja dalam suatu organisasi, atau organisasi sesuai dengan standar kinerja atau tujuan yang telah dietapkan terlebih dahulu”.

Indikator-Indikator Kinerja

Mangkunegara (2014:09). Menjelaskan bahwa "Kinerja adalah hasil kerja secara kualiats dan kuantitas yang dicapai oleh seseorang pegawai dalam melaksanakan tugasnya sesuai dengan tanggung jawab yang diberikan kepadanya".

Dari definisi diatas indikator kinerjanya adalah:

1. Kualitas, yaitu mutu hasil kerja yang didasarkan pada standar yang ditetapkan, di ukur melalui ketepatan, ketelitian, keterampilan, keberhasilan hasil kerja. 
2. Kuantitas, yaitu banyaknya hasil kerja sesuai dengan waktu kerja yang ada, yang perlu diperhatikan bukan hasil rutin tetapi seberapa cepat pekerjaan dapat diselesaikan.

3. Pelaksanaan tugas, yaitu kewajiban karyawan melakukan aktivitas atau kegiatan yang berhubungan dengan pekerjaan yang ditugaskan perusahaan.

4. Tanggung jawab, yaitu suatu akibat lebih dari pelaksanaan peranan, baik peranan itu merupakan hak dan kewajiban ataupun kekuasaan.

Hubungan antara Kompensasi dan Kinerja

Kutipan Sikula dalam Mangkunegara (2014:84) "kompensasi sangat penting bagi karyawan maupun majikan hal ini dikarenakan kompensasi merupakan sumber penghasilan karyawan, kompensasi juga merupakan gambaran dari status sosial bagi karyawan". Kompensasi yang diberikan kepada karyawan sangat berpengaruh pada kinerja karyawan, tingkat kepuasan kerja dan motivasi kerja, serta hasil kerja karyawan.

Organisasi yang menentukan tingkat kompensasi dengan mempertimbangkan standar kehidupan normal, akan memungkinkan karyawan bekerja dengan penuh semangat dan motivasi. Hal ini tingkat kepuasan kerja karyawan atau kinerja karyawanbanyak dipengaruhi oleh tingkat kompensasi yang diberikan kepada karyawan.

\section{Metodologi Peneltian}

Jenis penelitian ini adalah penelitian kuantitatif, menurut Sugiyono (2017:8) metode penelitian kuantitatif dapat diartikan sebagai "Metode penelitian yang berlandaskan pada filsafat positivisme, digunakan untuk meneliti pada populasi atau sampel tertentu, pengumpulan data menggunakan instrumen penelitian, analisis data bersifat kuantitatif/statistik, dengan tujuan untuk menguji hipotesis yang telah ditetapkan".

Desain penelitian ini adalah metode penelitian asosiatif, menurut Wiratna Sujarweni (2016:74) asosiatif adalah "Penelitian yang bertujuan untuk mengetahui hubungan antar dua variabel atau lebih". Dengan penelitian ini maka akan dapat dibangun suatu teori yang dapat berfungsi untuk menjelaskan, meramalkan, dan mengontrol satu gejala.

\section{Uji Asumsi Klasik}

Sebelum melakukan uji hipotesis, terlebih dahulu harus dilakukan uji asumsi klasik. Yang dimana uji asumsi klasik ini digunakan untuk mengetahui dan memahami suatu data apakah telah memenuhi standar dari pengujian asumsi klasik yaitu apakah data berdistribusi normal atau tidak, apakah data bersifat autokorelasi, multikolinearitas, atau heteroskedastisitas.

Didalam penelitian ini, penulis hanya menggunakan uji normalitas dan uji heteroskedastisitas karena uji autokorelasi hanya digunakan pada penelitian times series, dan uji multikolinearitas hanya digunakan pada penelitian dengan variabel independen lebih banyak. Berikut penjabarannya :

Uji Heterokedastisitas 
Uji ini bertujuan untuk menguji apakah dalam model regresi terjadi ketidaksamaan varian residual antara yang satu dengan yang lain. Jika varian residual dari satu pengamatan ke pengamatan yang lain tetap maka disebut homokedastisitas. Dan jika varian berbeda, disebut heterokedastisitas.

Uji Normalitas Data

Uji normalitas bertujuan untuk menguji apakah sampel yang digunakan mempunyai distribusi normal atau tidak. Dalam model regresi linier, asumsi ini ditunjukkan oleh nilai error yang berdistribusi normal. Model regresi yang baik adalah model regresi yang dimiliki distribusi normal atau mendekati normal, sehingga layak dilakukan pengujian secara statistik. Pengujian normalitas data menggunakan Test of Normality Kolmogorov-Smirnov dalam program SPSS. Menurut Sugiyono (2017:150) dasar pengambilan keputusan bisa dilakukan berdasarkan probabilitas (Asymtotic Significance), yaitu:

1. Jika probabilitas $>0,05$ maka distribusi dari model regresi adalah normal.

2. Jika probabilitas $<0,05$ maka distribusi dari model regresi adalah tidak normal.

\section{Analisa Regresi Linier Sederhana}

Regresi sederhana didasarkan pada pengaruh fungsional ataupun kausal satu variabel independen dengan suatu variabel dependen.

Persamaan umum regresi linier sederhana menurut Sugiyono (2015:261) adalah:

$\mathrm{Y}=\mathrm{a}+\mathrm{bX}$

Dimana

$\mathrm{y}=$ subyek dalam variabel dependen yang diprediksikan.

$\mathrm{a}=$ harga $\mathrm{Y}$ ketika harga $\mathrm{X}=0$ (harga konstan)

$\mathrm{b}=$ angka arah atau koefisien regresi, yang menunjukan angka peningkatan ataupun penurunan variabel dependen yang di dasarkan pada perubahan variabel independen. Bila (+) arah garis naik, dan bila (-) maka arah garis turun.

$\mathrm{X}=$ subyek pada variabel independen yang mempunyai nilai tertentu.

Nilai a dan b dapat diperoleh dengan menggunakan rumus sebagai berikut :

$$
\begin{aligned}
a & =\frac{\left(\sum Y_{i}\right)\left(\sum X_{i}^{2}\right)-\left(\sum X_{i}\right)\left(\sum X_{i} Y_{i}\right)}{n \sum X_{i}{ }^{2}-\left(\sum X_{i}\right)^{2}} \\
b & =\frac{n \sum X_{i} Y_{i}-\left(\sum X_{i}\right)\left(\sum Y_{i}\right)}{n \sum X_{i}{ }^{2}-\left(\sum X_{i}\right)^{2}}
\end{aligned}
$$

\section{Analisa Koefisien Determinasi}

Analisis koefisien determinasi digunakan untuk menyatakan besar kecilnya sumbangan variabel $(\mathrm{X})$ terhadap $(\mathrm{Y})$, dengan rumus sebagai berikut:

$$
\mathrm{Kd}=\mathrm{r}^{2} \mathrm{x} 100 \%
$$


Keterangan:
$\mathrm{r}=$ koefisien korelasi
$\mathrm{Kd}=$ Koefisien determinasi

Jika dalam output SPSS, koefisien determinasi terletak pada tabel Model Summary dan tertulis R Square. Dan menurut Sugiyono (2017:125), nilai R² sebesar 1, berarti pengaruh variabel $\mathrm{X}$ seluruhnya dijelaskan oleh variabel $\mathrm{Y}$ dan tidak ada faktor lain yang menyebabkan pengaruh variabel $\mathrm{Y}$. Jika nilai $\mathrm{R}^{2}$ berkisar 0 sampai dengan 1, berarti semakin kuat kemampuan variabel $\mathrm{X}$ dapat menjelaskan pengaruh variabel $\mathrm{Y}$.

\section{Pembahasan}

Uji heteroskedastisitas bertujuan untuk menguji apakah dalam sebuah model regresi terjadi ketidaksamaan varians atau residual dari satu pengamatan ke pengamatan yang lain. Model regresi yang baik adalah tidak terjadi heterokedastisitas. Untuk mengetahui ada atau tidaknya heterokedastisitas maka dapat digunakan metode grafik scatterplot yang dihasilkan dari output program SPSS versi 24. Apabila gambar menunjukkan bahwa titik - titik menyebar secara acak serta tersebar baik di atas maupun di bawah angka 0 pada sumbu Y, maka dapat disimpulkan bahwa tidak terjadi heterokedastisitas pada model regresi dan layak untuk digunakan dalam melakukan pengujian. Untuk lebih jelasnya dapat dilihat pada gambar berikut ini:

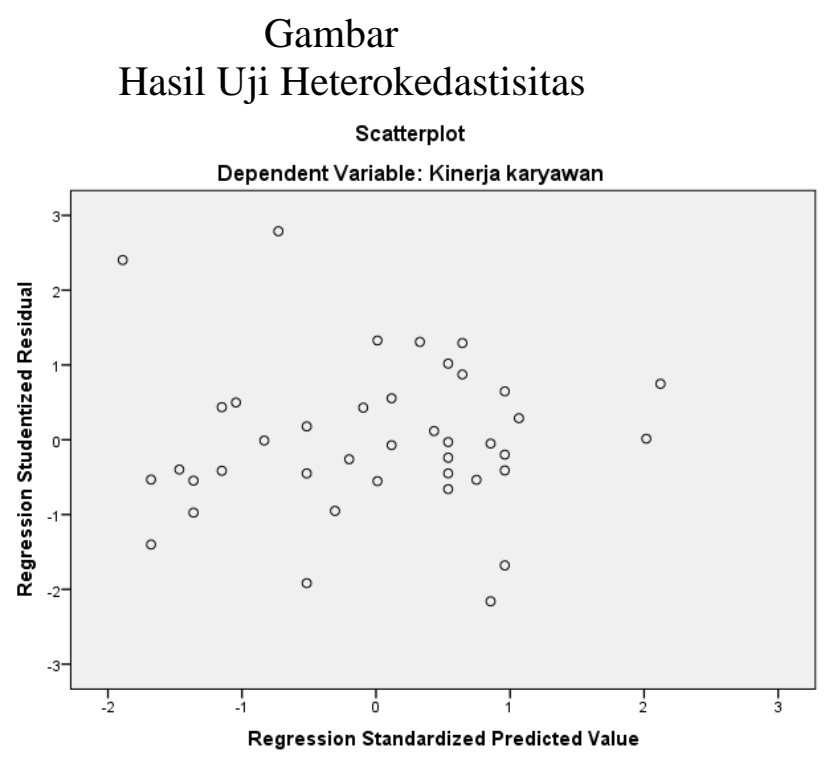

Sumber: Lampiran Output SPSS

Dari hasil grafik di atas bahwa terlihat titik - titik menyebar secara acak, tidak membentuk suatu pola tertentu yang jelas, serta tersebar baik di atas maupun di bawah angka 0 pada sumbu 
Y. hal ini dapat disimpulkan bahwa tidak terjadi heterokedastisitas pada model regresi dan layak untuk digunakan dalam melakukan pengujian.

\section{Uji Normalitas Data}

Uji normalitas bertujuan untuk menguji apakah sampel yang digunakan mempunyai distribusi normal atau tidak. Dalam model regresi linier, asumsi ini ditunjukkan oleh nilai error yang berdistribusi normal. Model regresi yang baik adalah model regresi yang memiliki distribusi normal atau mendekati normal, sehingga layak dilakukan pengujian secara statistik. Pengujian normalitas data menggunakan Test of Normality Kolmogorov-Smirnov dalam program SPSS. Dengan kriteria pengujian: menurut Singgih Santoso (2012:293), jika probabilitas > 0,05 maka distribusi dari model regresi adalah normal dan jika probabilitas < 0,05 maka distribusi dari model regresi adalah tidak normal. Untuk hasilnya dapat dilihat pada tabel dibawah ini: 
Uji Normalitas Kolmogorof Smirnov

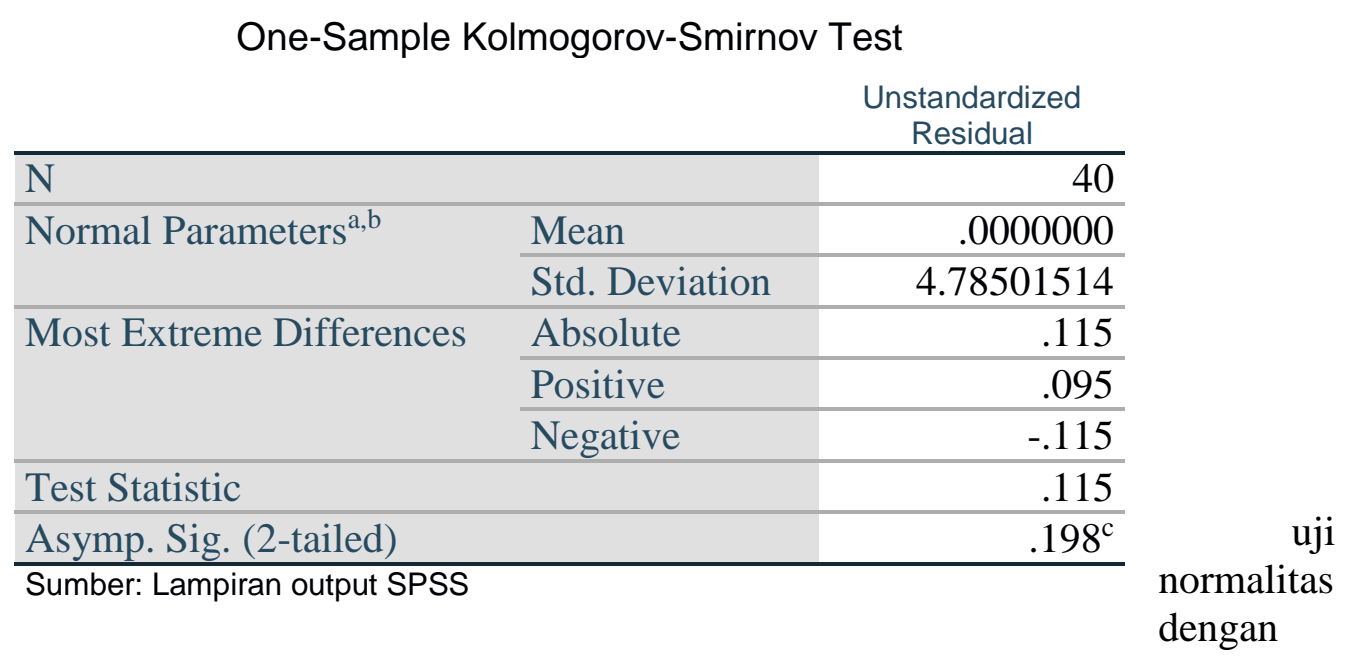

Kolmogorov-Smirov Test diatas, diketahui bahwa hasil nilai signifikansi dari SPSS sebesar 0,198 atau 19\% lebih besar dari 0,05 atau 5\%. Sehingga dapat disimpulkan bahwa data yang diuji berdistribusi normal.

Hasil Uji Koefisien Korelasi (r hitung)

Analisa koefisien korelasi bertujuan untuk menguji ada atau tidaknya hubungan antara variabel kompensasi dengan variabel kinerja karyawan.

Ketentuan dari uji korelasi adalah sebagai berikut:

1. Jika nilai $r>0$, artinya telah terjadi hubungan positif yaitu makin besar nilai variabel $\mathrm{X}$, maka makin besar pula nilai variabel $\mathrm{Y}$ atau makin kecil nilai variabel $\mathrm{X}$ maka makin kecil pula nilai variabel $\mathrm{Y}$.

2. Jika nilai $\mathrm{r}<0$, artinya telah terjadi hubungan yang negatif, yaitu makin kecil nilai variabel $\mathrm{X}$, maka akan makin kecil nilai variabel $Y$. atau makin kecil nilai variabel $\mathrm{X}$, maka semakin kecil nilai variabel Y.

3. Jika nilai $r=1$, artinya telah terjadi hubungan yang sempurna antara variabel $\mathrm{X}$ dengan Y.

Berdasarkan estimasi analisa koefisien korelasi dengan program SPSS 24 diperoleh hasil seperti tabel dibawah ini ini: 


\begin{tabular}{|c|c|c|c|}
\hline \multicolumn{4}{|c|}{ Hasil Uji Korelasi r hitung } \\
\hline \multicolumn{4}{|c|}{ Correlations } \\
\hline & & Kompensasi & Kinerja karyawan \\
\hline \multirow[t]{3}{*}{ Kompensasi } & Pearson Correlation & 1 & $.811^{\star *}$ \\
\hline & Sig. (2-tailed) & & .000 \\
\hline & $\mathrm{N}$ & 40 & 40 \\
\hline \multirow[t]{3}{*}{ Kinerja karyawan } & Pearson Correlation & $.811^{\star \star}$ & 1 \\
\hline & Sig. (2-tailed) & .000 & \\
\hline & $\mathrm{N}$ & 40 & 40 \\
\hline
\end{tabular}

Berdasarkan tabel di atas, terlihat bahwa kompensasi memiliki nilai r (korelasi) sebesar 0,811. Hal ini membuktikan bahwa kompensasi memiliki hubungan sebesar 0,811 atau $81,1 \%$. Dan berdasarkan nilai interval koefisien membuktikan bahwa kompensasi memiliki hubungan yang kuat dengan kinerja karyawan.

Hasil Uji Koefisien Determinasi $\left(\mathrm{R}^{2}\right)$

Koefisien determinasi merupakan besaran yang menunjukkan besarnya variasi variabel dependen yang dapat dijelaskan oleh variabel independennya. Dengan kata lain, koefisien determinasi ini digunakan untuk mengukur seberapa jauh variabel bebas dalam menerangkan variabel terikatnya. Nilai koefisien determinasi ditentukan dengan nilai R Square sebagaimana dapat dilihat pada tabel berikut ini:

\section{Hasil Uji Koefesien Determinasi}

\begin{tabular}{|c|c|c|c|c|}
\hline \multicolumn{5}{|c|}{ Model Summary } \\
\hline Model & $\mathrm{R}$ & R Square & $\begin{array}{l}\text { Adjusted R } \\
\text { Square }\end{array}$ & $\begin{array}{c}\text { Std. Error of the } \\
\text { Estimate }\end{array}$ \\
\hline 1 & $.811^{a}$ & .657 & .648 & 4.84757 \\
\hline
\end{tabular}

Hasil pengujian diatas, menunjukkan bahwa koefisien korelasinya (R) sebesar 0,811 atau $81,1 \%$. Hal ini menunjukkan bahwa variabel kompensasi mempunyai hubungan yang kuat terhadap kinerja karyawan. Sedangkan koefisien determinasi (R square) yang diperoleh sebesar 0,657 atau $65,7 \%$ artinya besarnya variabel kompensasi terhadap kinerja karyawan adalah 65,7\%. Sedangkan sisanya $(100 \%-65,7 \%=34,3 \%)$ dipengaruhi oleh variabel lain yang tidak dimasukan dalam penelitian ini. 


\section{Kesimpulan}

Berdasarkan hasil analisa data yang dilakukan, dan perhitungan statistik yang telah diuraikan pada halaman sebelumnya, maka dari penelitian ini dapat diambil kesimpulan sebagai berikut:

Berdasarkan hasil uji regresi linier sederhana maka dapat diperoleh persamaan $\mathrm{Y}=$ $19,978+0,564 \mathrm{X}$, yang dimana dari hasil uji tersebut dapat diketahui bahwa nilai dari $\mathrm{a}=$ 19,978 dan $b=0,564$. Artinya jika variabel kompensasi tidak ada $(X=0)$, maka kinerja karyawan hanya sebesar 19,978. Sedangkan setiap penambahan 1 nilai kompensasi, maka kinerja akan meningkat sebesar 0,564.

Berdasarkan hasil uji koefisien determinasi, bahwa presentase kompensasi mempengaruhi kinerja karyawan bagian produksi PT. Jaeil Indonesia dapat dilihat pada kolom Adjusted $R$ Square. Dan besarnya nilai Adjusted $R$ Square $\left(\mathrm{R}^{2}\right)$ sebesar 0,486 . Sehingga dapat disimpulkan bahwa kompensasi dapat memberikan kontribusi sebesar $48,6 \%$ terhadap kinerja karyawan bagian produksi PT. Jaeil Indonesia. Dan sisanya sebesar 51,4\% dipengaruhi oleh variabel lain yang tidak dimasukkan dalam penelitian ini.

Berdasarkan hasil uji t-test yang telah dilakukan maka dapat dilihat bahwa terdapat pengaruh positif yang signifikan antara kompensasi terhadap kinerja karyawan bagian produksi PT. Jaeil Indonesia dengan menunjukkan nilai $\rho$ lebih kecil dari nilai $\alpha(0,000<0,05)$ dan nilai

$\mathrm{t}_{\text {hitung }}>\mathrm{t}_{\text {tabel }}(5,146>2,04841)$. Dengan demikian Ho ditolak dan Ha diterima, yang berarti terdapat pengaruh yang signifikan antara kompensasi (X) terhadap kinerja karyawan (Y). Artinya kompensasi dapat meningkatkan kinerja karyawan (semakin tinggi kompensasi maka semakin tinggi pula kinerjanya).

\section{Saran}

Berdasarkan kesimpulan yang telah diuraikan di atas, maka ada beberapa saran yang dapat diberikan peneliti dan sekiranya dapat berguna bagi PT. Jaeil Indonesia;

Supaya kinerja karyawan bagian produksi PT. jaeil Indonesia baik dan meningkat, maka disarankan perusahaan harus terus memperhatikan para karyawannya dengan cara meningkatkan kompensasi para karyawannya seperti memberikan gaji sesuai UMR tiap tahunnya, memberikan tunjangan keuarga, serta bisa memberikan gaji sesuai dengan beban dan waktu kerja yang telah ditentukan.

Agar kinerja para karyawan terus meningkat dan tentunya dapat memberikan keuntungan yang maksimal bagi perusahaan. Hal ini berdasarkan hasil penelitian yang menyatakan bahwa kompensasi mempengaruhi kinerja karyawan bagian produksi PT. Jaeil Indonesia.

Dari hasil penelitian yang telah dilakukan, dapat dilihat bahwa variabel kompensasi (X) hanya menyumbang pengaruh sebesar $48,6 \%$ sedangkan sisanya $51,4 \%$ dipengaruhi oleh variabel lain yang tidak diteliti dalam penelitian ini. Oleh sebab itu, bagi pihak yang ingin 


\section{JESYA}

JURNAL EKONOMI \& EKONOMI SYARIAH

Jurnal Ekonomi \& Ekonomi Syariah Vol 2 No 2, Juni 2019

E-ISSN : 2599-3410 | P-ISSN : 4321-1234

melakukan penelitian yang sejenis dapat meneliti atau menganalisa variabel - variabel lain, untuk mengisi celah yang belum diteiliti didalam penelitian ini.

DAFTAR PUSTAKA 
Abdussamad, Zuchri, 2014, Pengaruh kompensasi terhadap produktivitas kerja karyawan. Google jurnal (10 Februari 2019)

Mangkunegara, Anwar, Prabu. 2014, Evaluasi Kinerja. Bandung: Refika Aditama.

Mangkunegara, Anwar, Prabu. 2015, Manajemen Sumber Daya Manusia Perusahaan. Bandung: Remaja Rosdakarya.

Mulyadi. 2015, Manajemen Sumber Daya Manusia. Bogor: IN MEDIA.

Nazir, Moh. 2014, Metode Penelitian. Ghalia Indonesia.

Rinawati, Neni, 2016. Pengaruh kompetensi kompensasi dan motivasi terhadap kinerja karyawan. Doaj>jurnal>view. (17 Februari 2019).

Siagian, Sondang, P. 2015, Manajemen Sumber Daya Manusia. Jakarta: Bumi Aksara.

Sinambela, Lijan, Poltak. 2018, Manajemen Sumber Daya Manusia. Jakarta: Bumi Aksara.

Sugiyono. 2014, Metode Penelitian Kuantitatif, Kualitatif, dan Kombinasi (Mixed Methods). Bandung: Alfabeta.

-----------. 2014, Metode Penelitian Manajemen. Bandung: Alfabeta.

-----------. 2015, Metode Penelitian Pendidikan. Bandung: Alfabeta.

-----------. 2017, Metode Penelitian Kuantitatif, Kualitatif Dan R\&D, Bandung: Alfabeta.

Sujarweni, Wiratna. 2016, Penelitian Akuntansi Dengan SPSS.Yogyakarta:Pustaka Baru Press.

Supriyadi, Lili . 2012. Pengaruh kompensasi, motivasi dan karakteristik pekerjaan terhadap kepuasan kerja pegawai. Doaj > jurnal > view. (12 Maret 2019)..

Sutrisno, Edi. 2009, Manajemen Sumber DayaManusia. Jakarta: Prenadamedia Group.

Wicaksana, Hardiansyah, Roni, Desmar, Marjam, Suddin Alwi, 2017, Kinerja yang dipengaruhi oleh lingkungan kerja, motivasi dan kompensasi.Doaj>jurnal>view (10 Februari 2019) 